\title{
A Religious and Economic Stopover in the Middle of Khorasan-e Razavi
}

\author{
Rocco Rante | ORCID: 0000-0003-0011-0392 \\ Researcher-Archaeologist, Louvre Museum, Paris, France \\ rocco.rante@louvre.fr \\ Meysam Labbaf-Khaniki | ORCID: 0000-0001-6292-1663 \\ Assistant Professor, Faculty of Literature and Humanities, University of Tehran, \\ Tehran, Iran \\ labbaf@ut.ac.ir
}

\begin{abstract}
Robat-e Sefid/Bazeh Hur is the name of two modern villages giving the name to a valley located in a strategic geographical point traversed by a main north-south caravan road. Archaeological evidence brought to light the meaning of this valley, in which religious and economic aspects show and testify to development of this region during the Sasanian and early Islamic epochs. They highlight its role as a stopover for caravans in the past as today.
\end{abstract}

\section{Keywords}

trade - caravan - religious - chahartaq - mușallā

The joint Franco-Iranian archaeological mission in Khorasan, directed respectively by Dr. Rocco Rante and Dr. Meysam Labbaf-Khaniki in 2018, carried out different archaeological activities on the site of Robat-e Sefid/Bazeh Hur, in Khorasan-e Razavi (Fig. 1). The scientific program of the joint mission focuses on the study of the civilizations and cultures of Khorasan, between the Parthian period and the early Islamic time. The goals of this research program mainly are to identify the major sites founded or inhabited during this time-gap in this vast region, study their origin, apprehend their links with the landscape and their evolution in terms both of urban culture and material culture, and finally to study their relations with the surrounding political territories. The first objectives are thus to identify the human groups which lived and crossed through this region, apprehend their human and territorial evolution, basing the results on solid geo-archaeological data issues from a collaboration with geomorphologists, archaeozoologists, and archaeobotanists. A better knowledge of this territory and of its populations also permits us to reconsider the urban phenomenon in the broader context of these cultural regions, and to compare and consider it through the prism of its relations between these urban entities and with Iranian cities to the west and to the east.

In terms of Sasanian administrative and cultural areas, the valley of Robat-e Sefid/ Bazeh Hur is in Abarshahr (Gyselen, 1989: 84-5), between the area of Nishapur and Tus, 


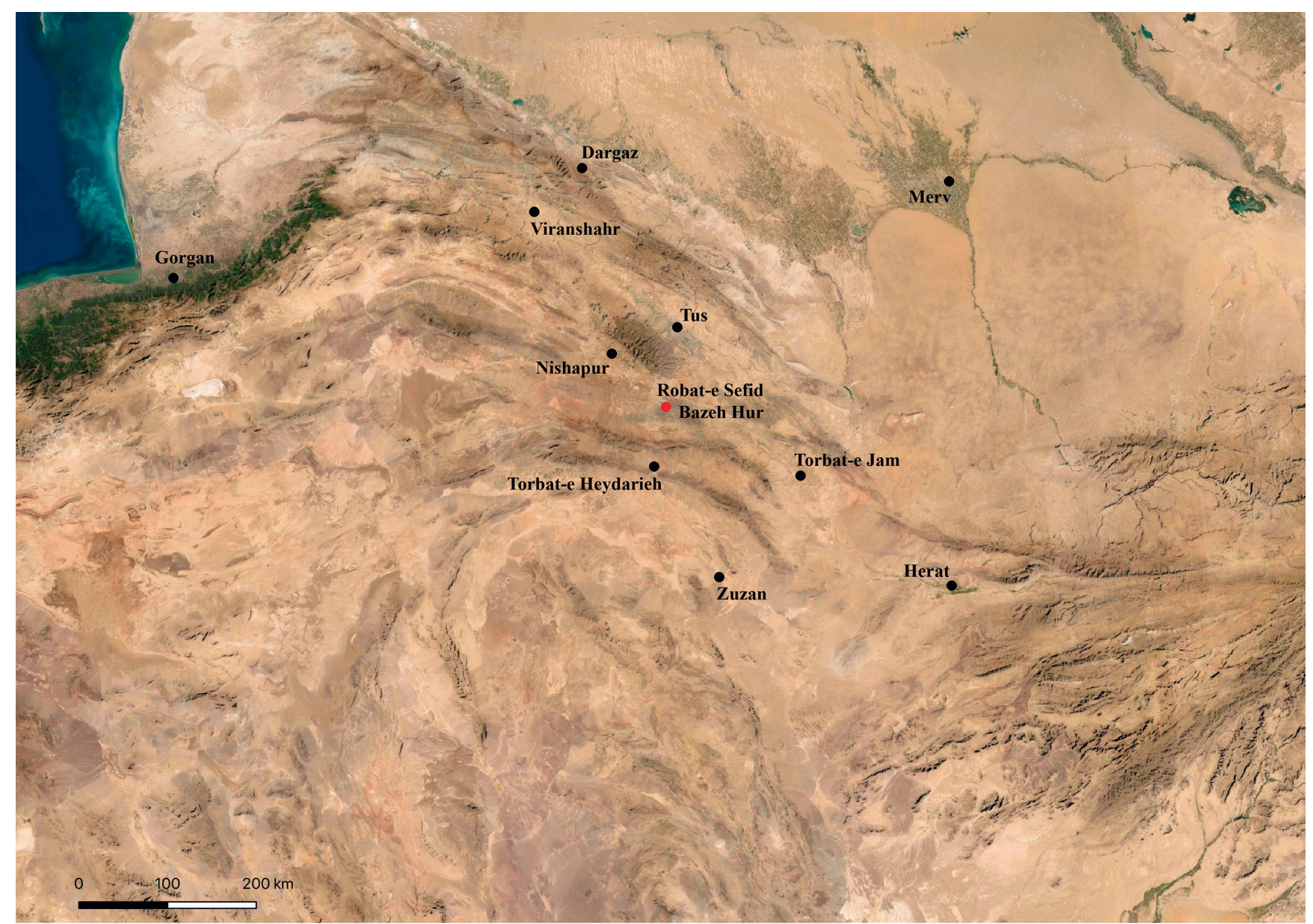

to the north, and the more arid areas of Bardaskan and Torbat-e Hedariyeh, ${ }^{1}$ and Zuzan (Marquart, 1901: 74-5), to the south. At the eastern side, the valley is separated from FIGURE 1

General satellite map of Khorasan (C) WORLD IMAGERY Farhadgird, Fariman, and Torbat-e Jam, through the roads leading to Afghanistan, by an important mountain range. This location gives to this valley a key geo-strategical situation, moreover because through it crossed the main caravan road joining the southern Kerman province to the northern territories.

Although it seems that no nineteenth-century travelers mentioned this valley, except for H.W. Bellew (see below), it is possible that it appears in a sketch of Khorasan carried out by James Fraser during his journey into Khorasan in 1821-2. In his main sketch (Fraser, 1984), he located, between Robat-e Sangbast and Torbat-e Heydarieh, the site of Robat-e Kameh, which is crossed by the main ancient road. The author did not mention this site in his descriptions, perhaps because of its exiguity.

It is instead certain that, in his Topographie von Persien, Tomaschek mentions the village of Robat-e Sefid and clearly draws it in his map (Tomaschek, 1972: 167). He does not dedicate any description to the rustaq, but it is well located between Kafirkala and Torbat-e Heydarieh.

Since 2014 Meysam Labbaf-Khaniki worked on the area of the chahartaq of Bazeh Hur. The aim of the Iranian archaeologist was to study the monument itself, carrying out the plan of the original building and identifying further structures around it (Labbaf-Khaniki, 2017, 2019).

In 2018, a joint Franco-Iranian mission decided to study the whole valley, its human occupations, its geomorphology, its implication in the large territory of Khorasan-e Razavi, as well as the monuments surrounding the chahartaq, namely, the raised-up 
temple of Qaleh Dokhtar. The area of study concerned the western side of the valley, today cut by a main road leading from Mashhad toward Torbat-e Heydarieh. After a first survey, this eastern area has been divided into two main zones, the southern one in which are concentrated Sasanian monuments, and the northern one in which are concentrated Islamic monuments. Both zones are situated along the ancient road linking Nishapur or Mashhad to Torbat-e Heydarieh or Kerman southward.

\section{$2 \quad$ Geographical Setting and Geomorphological Data}

The valley in which rise the villages of Bazeh Hur and Robat-e Sefid is located along the ancient road joining Mashhad (anc. Tūs) to Torbat-e Heydarieh (anc. Zāveh), crossing the villages of Asad Abad and Robat-e Sang southward (Fig. 2). The valley is distant circa $100 \mathrm{~km}$ from Mashhad and approximately the same from Nishapur, if one drives through Soltanabad-e Namak. The valley is closed and protected by mountains all around, the northern and southern ones outlining the shape of it, giving thus an orientation east-west. This area is characterized by the presence of a geological lock of weak gypsum mountains, of the same orientation east-west, presenting graduated shades of white, rose, and reddish. A large riverbed, now dry, crosses this valley. Reaching in some places 4,ooo $\mathrm{m}^{3}$ high, this ancient watercourse appears disproportionate compared to the whole valley, which covers an area of circa $9 \mathrm{~km}^{2}$. The river, called Kal-e Divune,

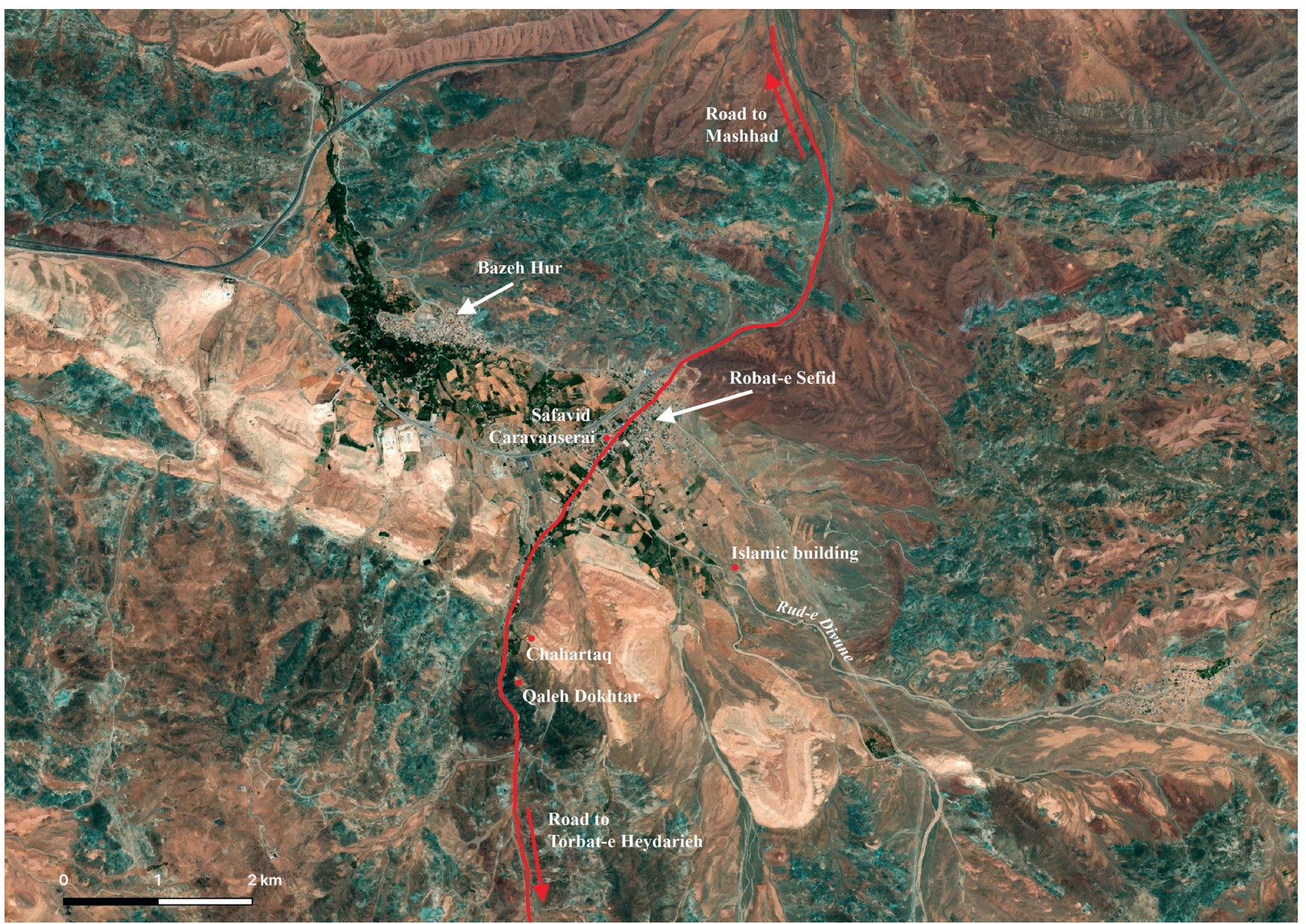

FIGURE 2

Geographical map of the valley

Robat-e Sefid/Bazeh Hur

(C) WORLD IMAGERY; RANTE 2021 


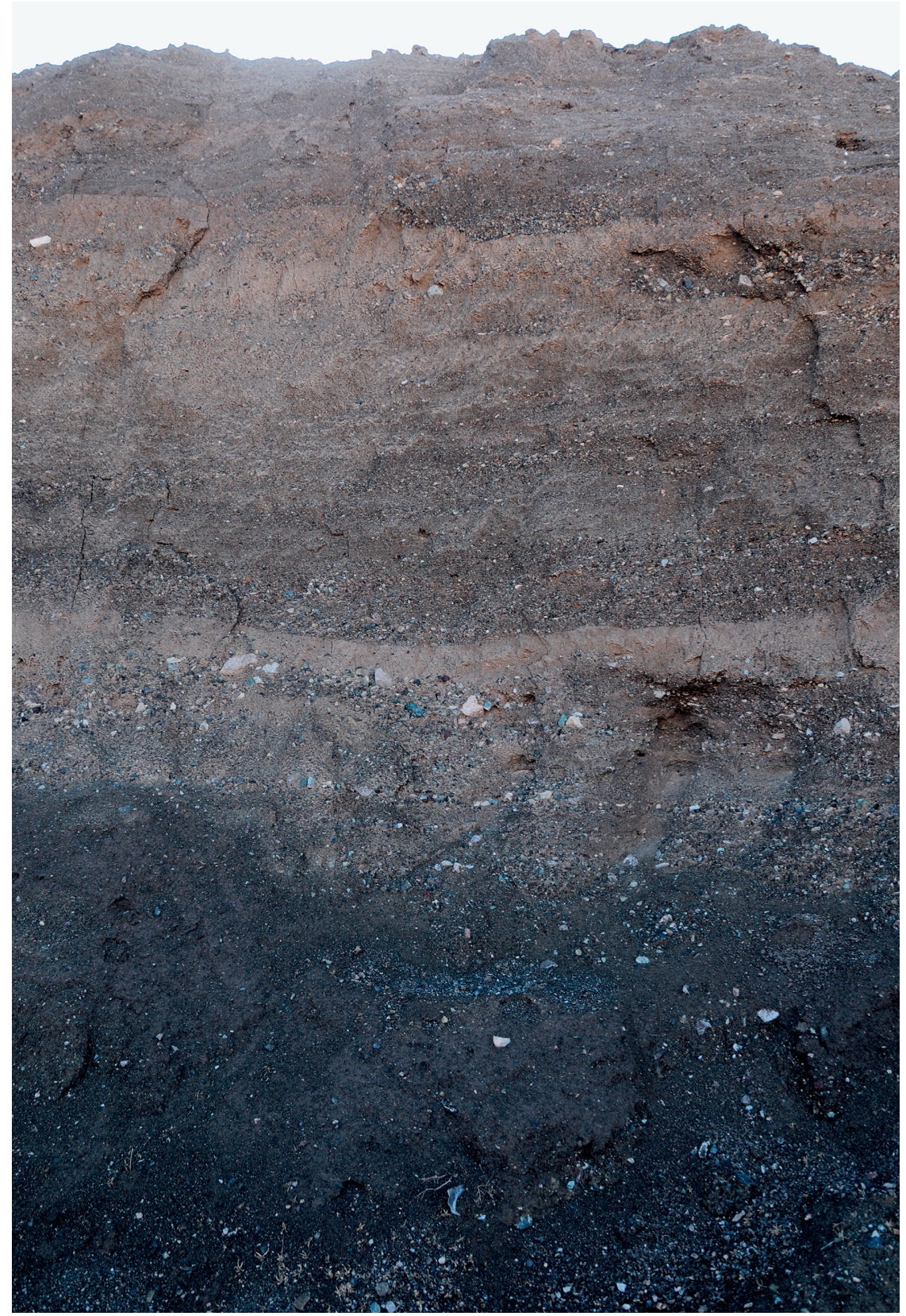

began its path approximately $10 \mathrm{~km}$ upstream to the east, from the eastern mountain range dividing the valley from the main road going to Afghanistan. It is also supplied by an important arm, shorter and coming from the southeast, joining the main channel precisely at the beginning of the earliest Islamic settlements. Other smaller rivers flowing from the mountains around also supplied Kal-e Divune, which finally flows into the Shurah Rud, several kilometers more to the northwest.

The surveys carried out into the dried watercourse clearly show the geomorphological dynamics at the origin of this landscape. The upper layer of the riverbed, at the altitude of $1,760 \mathrm{~m}^{2}$, is constituted of gray fine alluvial sediment (Fig. 3). This whole eastern area of the valley (we have not surveyed the western side) is characterized by a thick layer of this sediment constituted of gray/black sand and very small stone chippings. The sediment is, in some parts, mixed with pure loess, in a randomized setting, but shows a horizontal dynamic. Sometimes it is thicker, sometimes thinner. On average 5 meters thick $(1,770-5 \mathrm{~m})$, in some parts this sediment can reach a thickness of more
FIGURE 3

Sediment section of the northern wall of the Rud-e Divune riverbed (C) RANTE 2021 
FIGURE 4

Cross section of the Islamic area, from the riverbed to Trench A (C) RILIEVI SLR 2018
FIGURE 5

Gypsum carries, photo from the south

(C) RANTE 2018
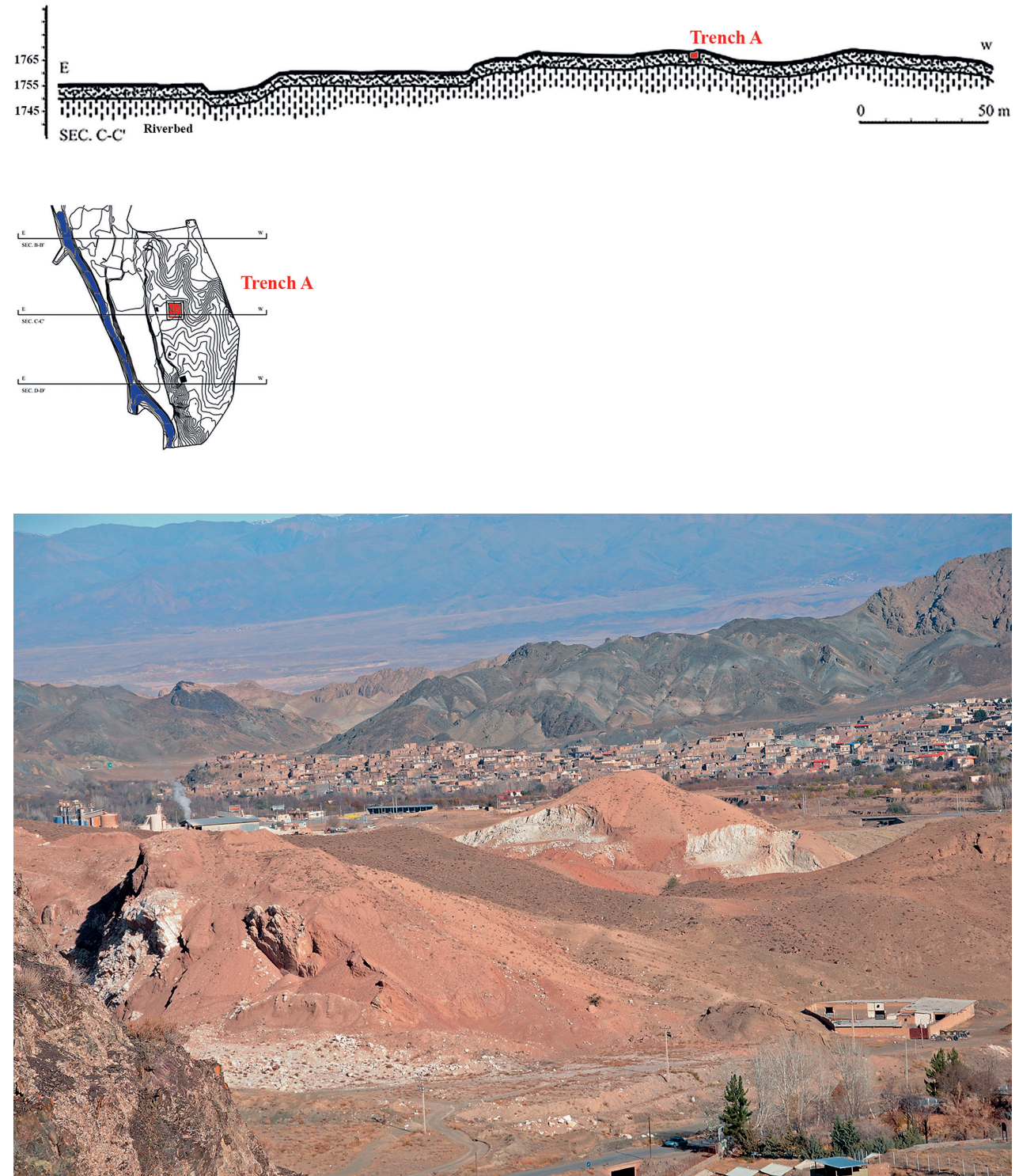

than 10 meters (Fig. 4). The earliest human populations settled above this layer at an altitude of $1,775 \mathrm{~m}$.

According to Eric Fouache, ${ }^{3}$ after a first observation of the documentation, this sediment consists of rough alluvial deposits testifying to a very dynamic period with a system of torrential flow which later carved out the riverbed. The river being dry since at least the 1960s, as shown by the aerial photos of this time, it appears possible that a reorganization of the territory took place a long time ago. It is, however, also possible that an embankment has been made upstream transforming the landscape as we can observe today.

This first geomorphological overview needs further observation and studies in the field, in order to better recognize the different dynamics and their origins. Further missions will be planned in which osL (Optical Stimulated Luminescence) analyses can be realized on this gray sediment.

To the south, along the ancient road joining the Kuh-e Binalud region to Quhestan, a stream flows south-northwest along the mountains, delimiting the southern part of the valley. Into this stream flows a small source coming up from the relief. Given the monuments discovered above this geographical relief and more generally around this area, it seems to have held a holy function. 
To its southern limit, the valley is characterized by a long range of gypsum reliefs, easily recognizable by its whiter rock, in contrast with the black one more to the south or to the northern side of the valley (Fig. 5). While today several mines and factories for the extraction of gypsum have settled along the northern mountain line, this was not the case in the 196os, as shown by aerial photos of that time. This does not imply that this material was not extracted before the 196os. On the contrary, the huge quantity of stuccoes brought to light during the excavation of Qaleh Dokhtar, on the top of the mountain south of the village, strongly suggests that gypsum was extracted in this valley. ${ }^{4}$ In view of its strategic location and the existence of such mines, it is possible to suggest that material for stuccoes found in Nishapur, ${ }^{5}$ Sangbast, or elsewhere in this region was extracted here in Robat-e Sefid.

\section{Historical Settlements}

The archaeological area is constituted of two main zones in which human occupations have been observed (Fig. 6). In the southern part a chahartaq rises directly above a

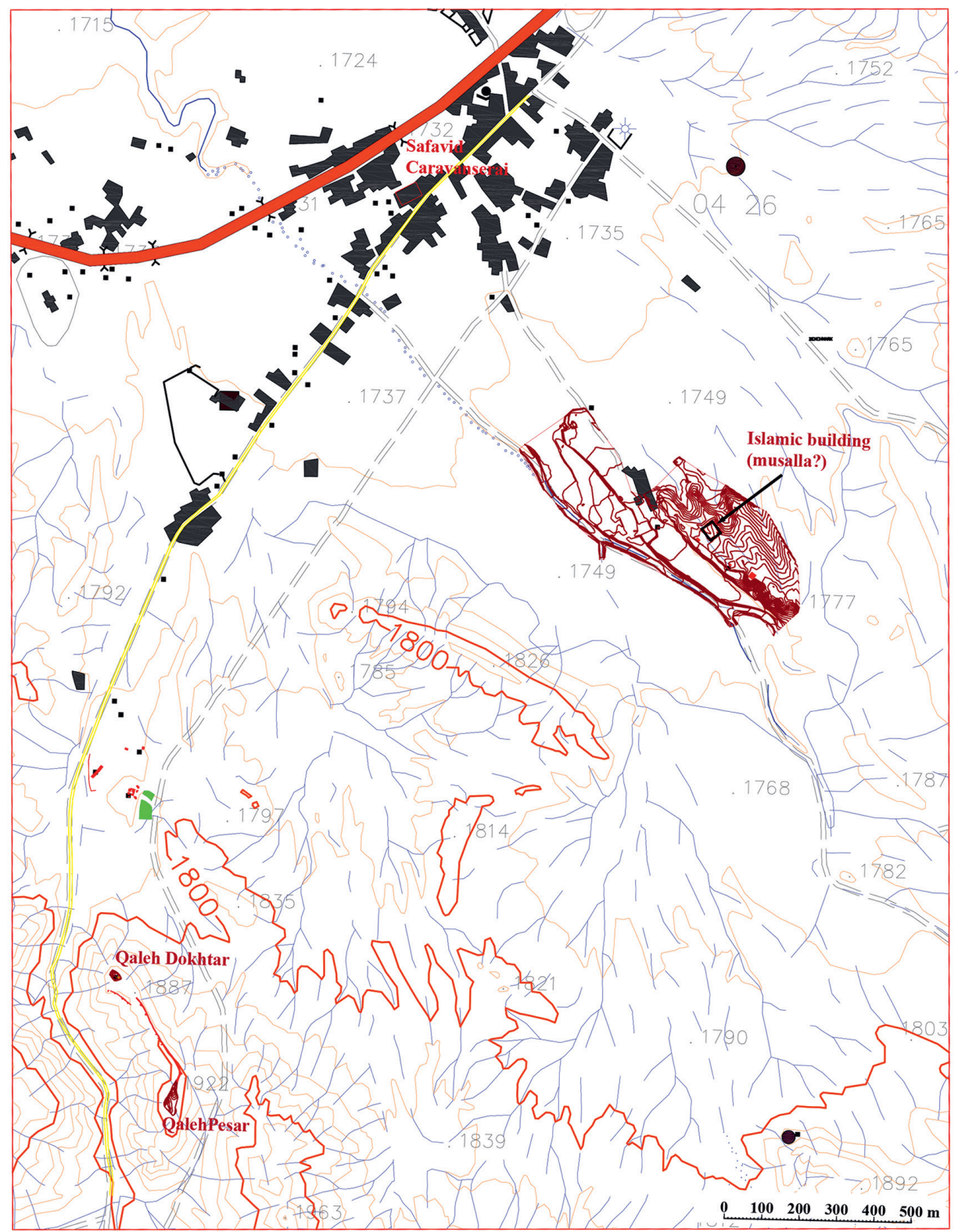

FIGURE 6

Topographical and archaeological map of the site

(c) RILIEVI SLR 2018 
FIGURE 7

Photo of the mud brick wall joining Qaleh Dokhtar and Qaleh Pesar

(C) RANTE 2018

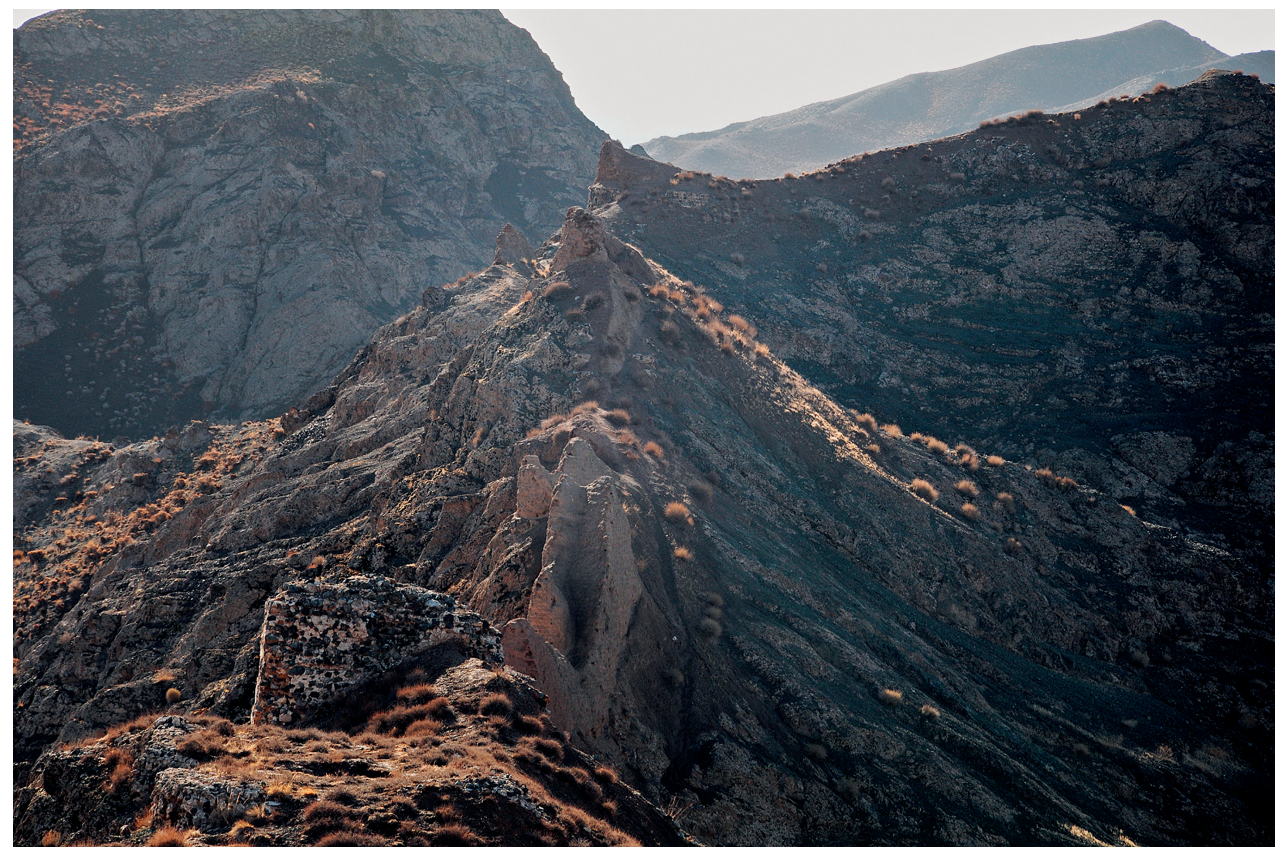

natural platform, constituted of gray sediment, reaching an altitude of 1,784.55 m. More to the south, on the peak of a mountain limiting the narrow corridor of the ancient road, two monuments rise up, namely, Qaleh Dokhtar, to the northwest, and Qaleh Pesar, ${ }^{6}$ to the southeast. Both were joined by a strong fortification wall, clearly visible also from the foot of the mountain as well (Fig. 7). These monuments reach an altitude of circa 1,900.5 $\mathrm{m}$; the base of the mountain is at the altitude of circa 1,800 $\mathrm{m}$.

Further to the north, at circa 1,500 $\mathrm{m}$ from the chahartaq following an orientation of north-east, dense human occupations scattered over around 11 hectares, at the righthand side of the dried river. This occupation rises over smoothed reliefs, today occupied by agricultural fields. The area is called Abbas Abad. Here, a monument located along the river has been brought to light in 2018. Another caravanserai is still visible in the modern village of Robat-e Sefid, only $1.35 \mathrm{~km}$ to the west. It is dated to the Safavids.

\subsection{The chahartaq of Bazeh Hur}

The first mention of the chahartaq of Bazeh Hur (Fig. 8) comes from Sir Henry Walter Bellew, a British physician serving in Afghanistan, in his From the Indus to the Tigris (Bellew, 1874). He mentioned this area most probably during his travels, thus describing the gorge, today called Chehel Dokhtaran, the castle on the top of the mountain outlining the gorge, and then referring to the chahartaq. Later, other explorers such as Ernst Diez (1923) and Ernst Herzfeld (1942) more accurately described this monument and left documents as the first picture, by the former, or a detailed sketch, by the latter. In 1925, Herzfeld provided a consistent description of the monument, in which he also identified a lateral structure, today disappeared, and proposed that it was a fire temple with the other monument on the top of the mountain.

Later, André Godard, who recorded the monument in the Iran National Heritage List, also provided documentation consisting of further photos (Fig. 9), and Donald Wilber published his description in 1946, also mentioning a lateral ambulatory. Schippmann (1971), Hallier (1975), but also Kleiss (1978), Huff (1975; 1989: 634ff.), and more recently Rajabali Labbaf-Khaniki (1378/1999), Karim Pirnia (1386/2007), and Hozhabri (2013) all identified different elements of this monument, each of them reconstituting through their documentation more and more of its original structure. 

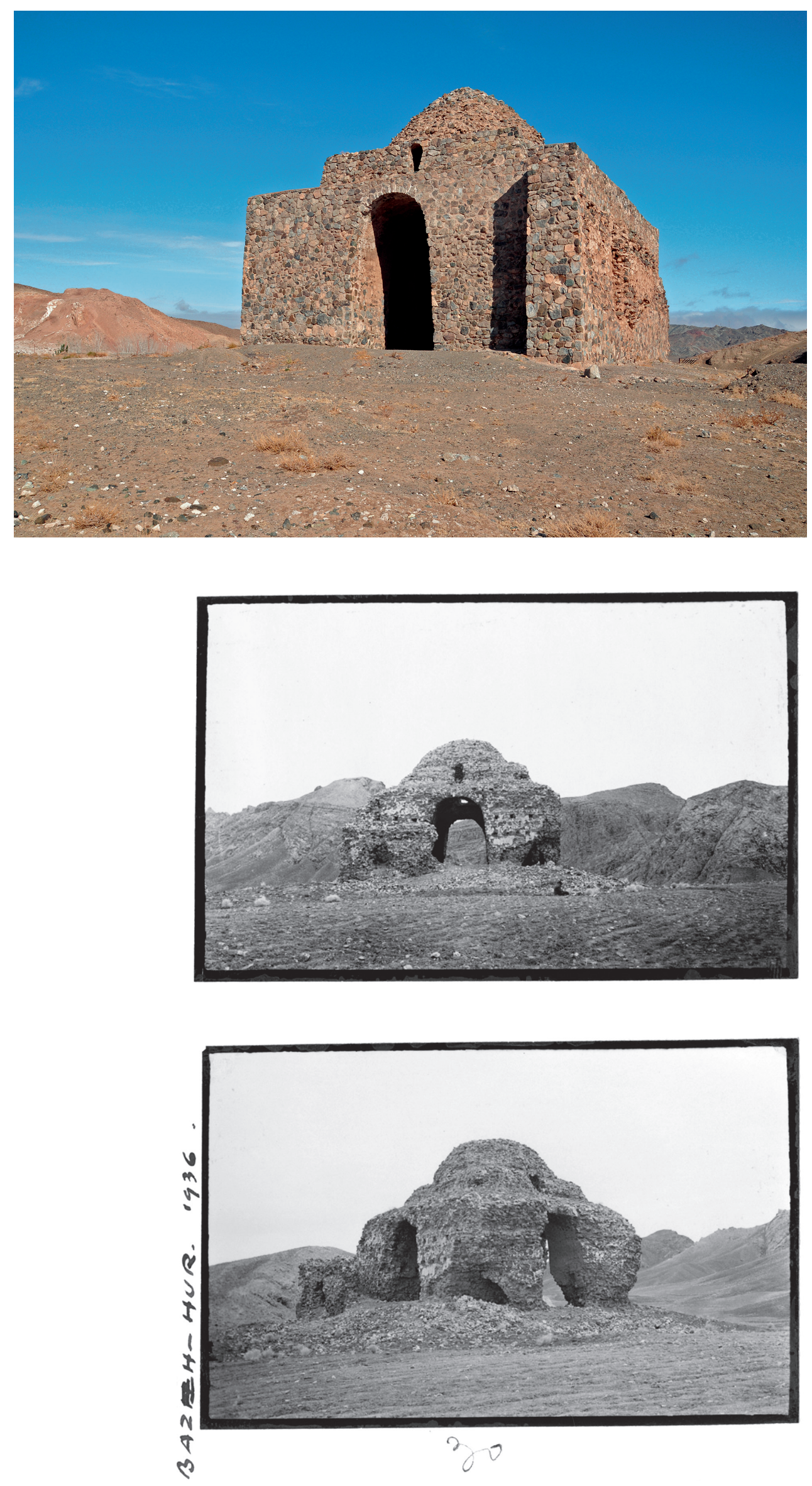

FIGURE 8

Chahartaq of Bazeh Hur

(C) RANTE 2021
FIGURE 9

Two old pictures of the chahartaq of Bazeh Hur realized by André

Godard

(C) GODARD (1938) 
Although each scholar proposed their own idea of the monument, all of them were inclined to ascribe it a Sasanian origin ${ }^{8}$ and both a defensive and religious function.

The archaeological activities focused on the chahartaq of Bazeh Hur were realized in 2014 and 2017, under the direction of Meysam Labbaf-Khaniki (Labbaf-Khaniki, 2017, 2019). The intent of the Iranian archaeologist was to study the whole monument, drawing on the previous studies and data provided by the scholars previously mentioned. The archaeological investigation brought to light a columned hall/porch on the eastern side of the chahartaq, thus attesting a typical Sasanian organization of the space, as also shown in other monuments, religious as well as secular, namely, the columned hall of Takht-e Soleiman (Boyce, 2011; Naumann, 1967: 305off.; Schippmann, 1971: 329ff.), the Zoroastrian complex of Bandian (Rahbar, 2004), the palace of Kish (Moorey, 1979), and the palace of Sarvistan (Bier, 1986).

Concerning its function, the latest excavations of 2018 shed light on the fog in which archaeologists were lost. In fact, the excavation of Qaleh Dokhtar on the top of the southern mountain brought to light its function as a fire temple, and thus its connection with the lower complex, probably dividing in two sides, private and public, of the same area, but certainly the lower one giving access for people traveling on the ancient road to the lower monument and providing limited access to the upper temple.

\subsection{Qaleh Dokhtar}

The excavation of Qaleh Dokhtar ${ }^{9}$ initially presented several difficulties. The site is located on the top of a mountain spur, circa 20 meters large, at an altitude of 150 meters from the plain, which imposed a limited number of archaeologists and workers, and thus material. ${ }^{10}$ The strategy was therefore to get the topography of the site, excavate by square trenches the whole surface, and try to have dating material (Fig. 10).

The excavation firstly brought to light a square basin, possibly for containing water for ceremonies. The walls were covered with a mixed material, probably waterproof, located in a room, likely at the entry of the building. At the bottom of the basin lay several big fragments of columns, collapsed from the room floor. The rest of those columns

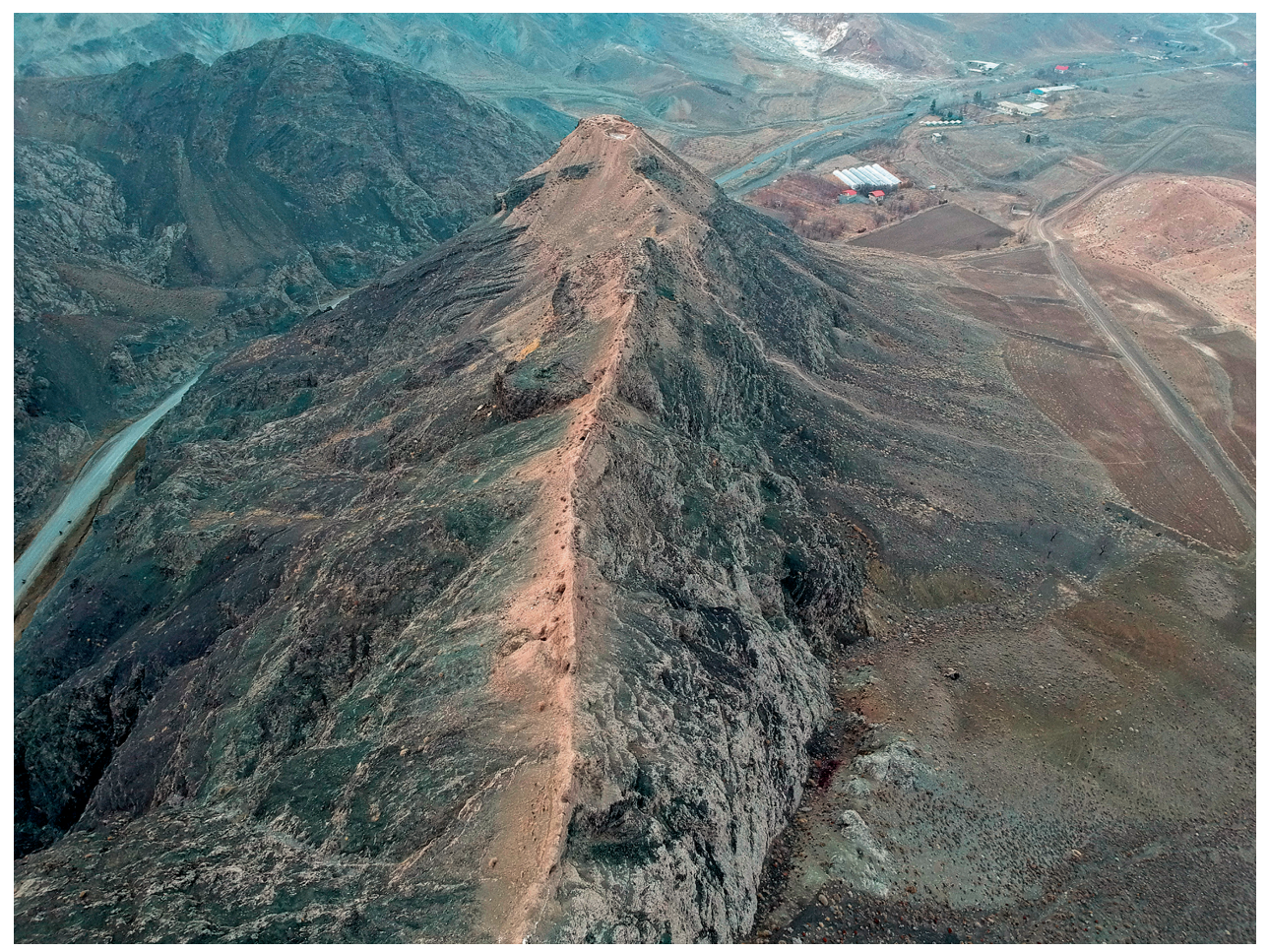

FIGURE 10

Aerial photo of the top of the relief on which Qaleh Dokhtar has been erected and overview of a part of the valley

(C) LABBAF 2018 


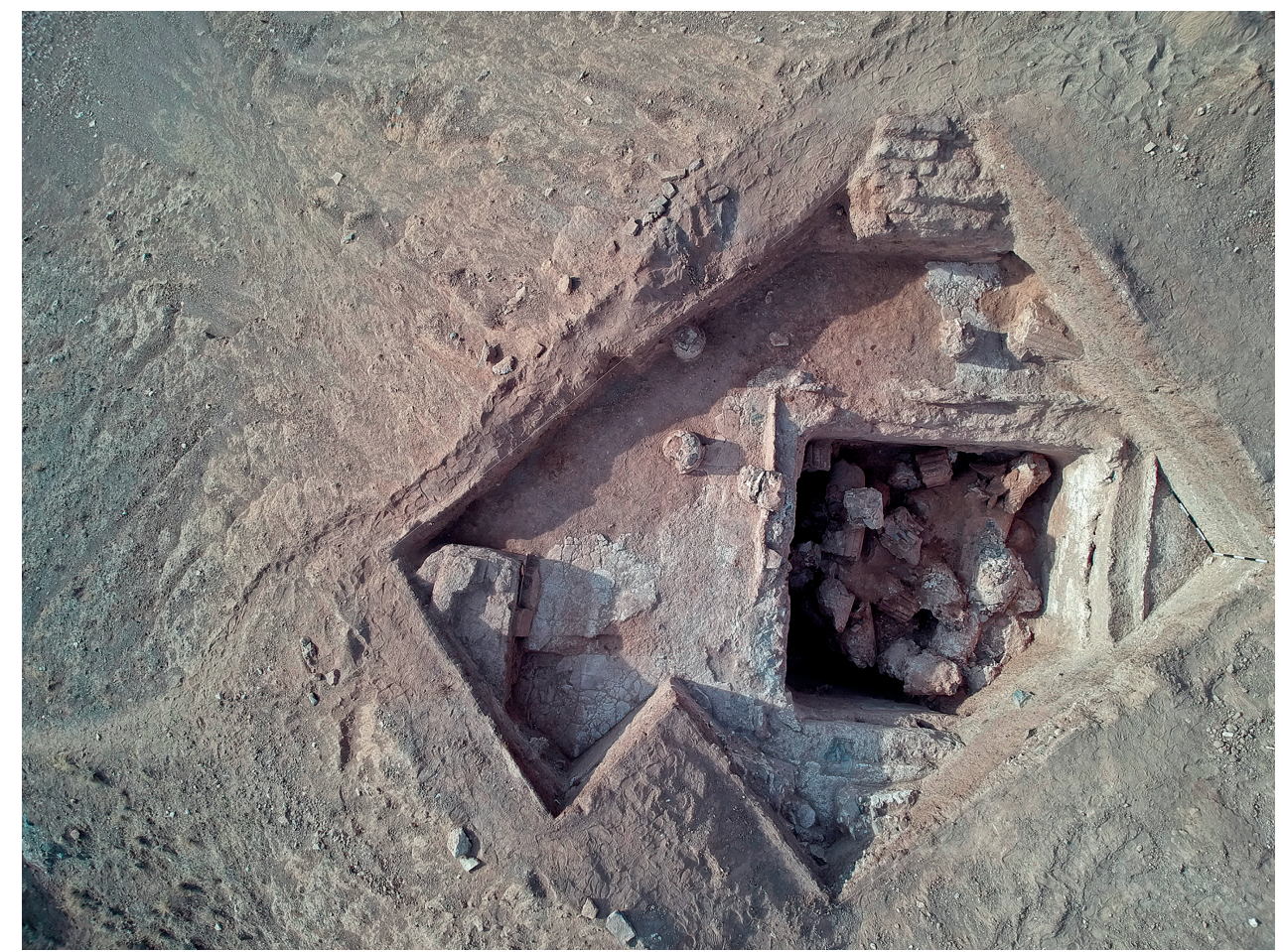

were still in situ all around the basin. These columns were all decorated with stucco motifs, representing the Sasanian vocabulary of that epoch (Fig. 11). Following the dynamics of destruction, at the origin the columns were organized around the basin, probably supporting a roof or an impluvium.

The western part of the site was occupied by a large space, in which it seems there was the structure hosting the holy fire, probably a further chahartaq. It was possibly encircled by a corridor. Comparisons with these architectural features are many, ${ }^{11}$ although the conservation state of Qaleh Dokhtar does not permit one to go farther. Its specific location identifies it as a fire temple possibly employed for keeping the holy fire and for ceremonies.

There are some examples showing that the tradition which located a religious monument on the top of a relief has been repeated also during Islamic time, as shown by Siroux in Qom (Godard, 1938: 120, fig. 75).

\subsection{Abbas Abad}

Only 1.5 kilometers east from the chahartaq of Bazeh Hur, beyond Kal-e Divune, the surveys brought to light intense human occupations dated to the Islamic period. The pottery fragments observed covered a chronological span from the ninth to the tenth centuries to the Mongol period. Fragments of typologies such as buffware, slip-painted with black inscription, pottery painted underglaze, and ladjvardina were collected. Unglazed ceramic has also been collected, of which the shapes essentially concern jugs, jars, bowls, and pots. Sasanian characteristic ceramic was, at the state of research, totally absent in this area.

Topographic investigations brought to light an approximately square monument, located in the center of a small natural mound, at the limits of the right bank of the main river. Excavations show that it was directly built on the gray sediment coming from the past alluvial dynamics of this water basin. Archaeological evidence shows that the monument was constructed with strong walls and presented a central courtyard, with an entrance on the northeastern side (Fig. 12). Unfortunately, the very bad
FIGURE 11

Aerial photo of the water basin for ceremonial tasks in Qaleh Dokhtar (C) LABBAF 2018 
FIGURE 12

Aerial photo from the 1960 s showing the archaeological area (C) SAZEMAN-E NAQSH-E BARDARI, TEHRAN

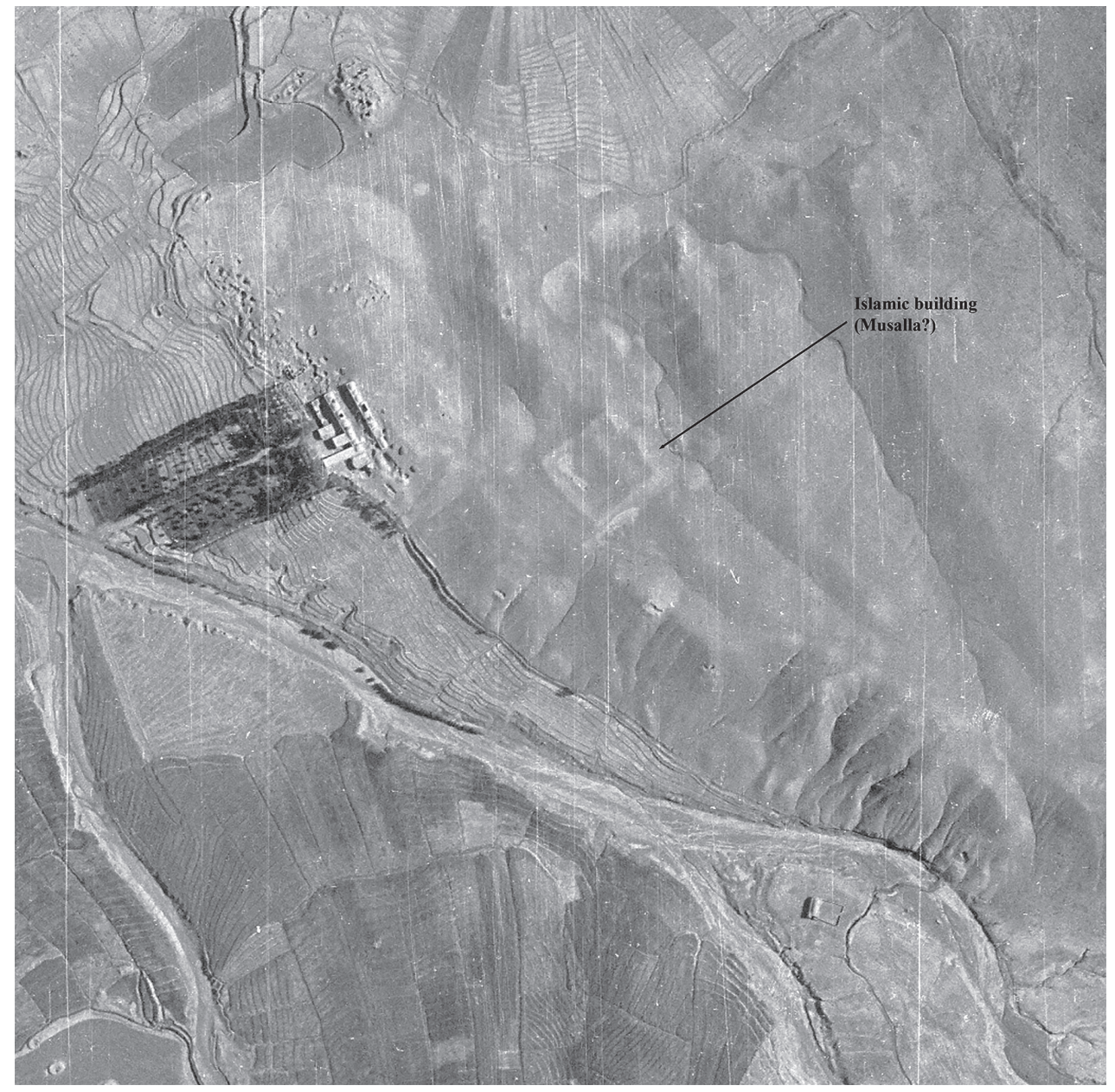

conservation state of the southwestern side prevented further research. Each side of the building measures $83.43 \mathrm{~m}$; the area is $6,960.56 \mathrm{~m}^{2}$. The wall is constituted of a pisé layer circa $1.2 \mathrm{~m}$ high, the foundation directly laid on the natural sediment, and an upper layer $1.4 \mathrm{~m}$ high constituted of mud brick measuring $60 \times 50 \times 10 \mathrm{~cm}$. The wall is $2.7 \mathrm{~m}$ large, testifying its strongness and its function of assuring people inside.

Some meters to the west, between the former square monument and the main ancient road, despite the destruction caused by people bringing mud brick for fields, a large mound recognizable from 196os aerial photos has been identified. This organization seems to better link all spaces with the main road crossing the valley. A first excavation on a very thin layer brought to light Islamic occupations, datable to the twelfth to thirteenth centuries, which directly leaned on the gray natural sediment. The place being largely destroyed, it is no longer possible to attest any other features.

It is not yet possible to gain precise archaeological knowledge of the former square monument. But its architecture, its location relating to the road, and the ceramic observed can support the idea that it could have been a caravanserai, or a place for praying, possibly a mușalla. ${ }^{12}$

\subsection{The Caravanserai of Robat-e Sefid}

Along the ancient road, oriented north-south, joining Mashhad to Torbat-e Heydarieh, in the center of which today is called the village of Robat-e Sefid, rises a large caravanserai (Labbaf-Khaniki et al., 1392/2013: 373-80; Fig. 13), ${ }^{13}$ from which the village got its name. It seems that it was called Robat-e Sefid, "the white caravanserai," because 


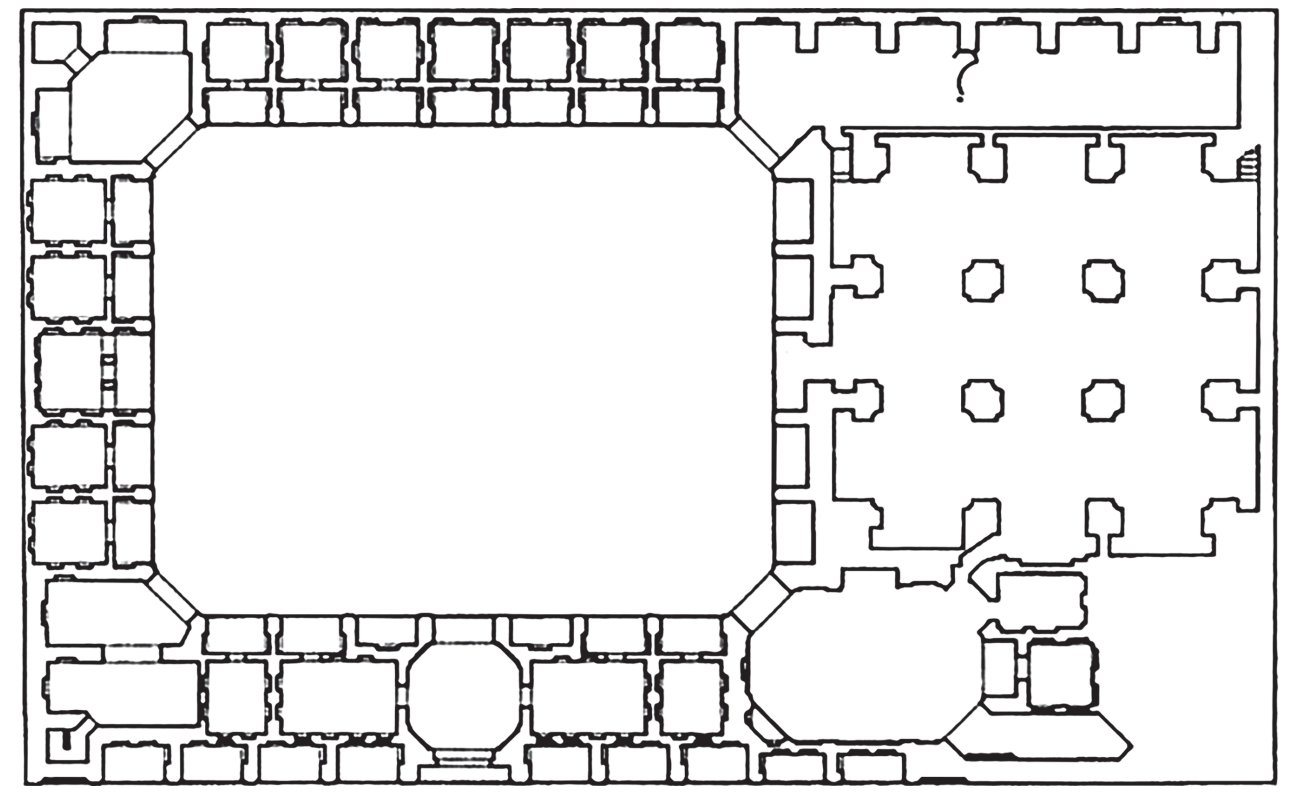

its walls were covered with white plaster, as was the custom, especially in the Safavid period to which it has been dated. It covers an area of $2,361 \mathrm{~m}^{2}$ and is constituted of four iwans encircling a courtyard, in which open cells. It is also provided with a floor. ${ }^{14}$

\section{$4 \quad$ Meaning and Impact of the Valley of Robat-e Sefid}

In a geographical location which is $75 \mathrm{~km}$ from Nishapur, $7 \mathrm{o} \mathrm{km}$ from Torbat-e Hedaryieh, $80 \mathrm{~km}$ from Tus, and $70 \mathrm{~km}$ from Farhadgird or Fariman, the valley of Robat-e Sefid settles in a strategic place of Khorasan-e Razavi. The valley could have been reached in two days from the previously mentioned ancient cities. From a socio-territorial point of view, archaeological evidence shows its rural character. But from a religious, as well as sociopolitical and economic, point of view, the same evidence shows its undeniable importance.

Robat-e Sefid was "nothing else" but a valley located between different main cities, which is perhaps the reason why historical sources were silent regarding it. Archaeological evidence, nevertheless, well shows its links to the politic and economic increasing of this eastern region under the Sasanians.

Rezakhani (2017:121-38) recently published an interesting reflection about Khorasan, in which he pointed out the autonomous regional character of the origin of this territory. This point of view substantially reiterates what has been already published in a previous article (Rante, 2015), treating two territorial entities, "Proper Khorasan" and its development to "Greater Khorasan," starting from historical and archaeological approaches. It is, however, interesting that Rezakhani moves the center of the origin of this development to the east of the current Khorasan, while Rante (2015) carried out this development from the inner Khorasan territory, coming back to the Parthian era, which is still to be demonstrated, but remains an interesting hypothesis.

What is essential in both discussions about Khorasan is that, after the subjugation of the Hephthalites and the arrival of Khosrow I in the sixth century CE, the region underwent an intense period of development in terms of territorial expansion and trade. This does not mean that the concept of an "eastern territory"15 did not exist before, but since that historical context marked a territorial "vacuum" in the regions south of Oxus, the
FIGURE 13

The Safavid caravanserai of Robat-e Sefid

(C) LABBAF-KHANIKI ET AL. $(1392 / 2013)$ 
Sasanians occupied these regions and expanded their influence from there (Frye, 1983: 156), until the mountain range of Badakhshan (Rante, 2015: 9-17).

It is at that time that the whole eastern Iran increased its exchanges, development of roads, and trade. ${ }^{16}$ At the same time, the valley of Robat-e Sefid became a key passage between the southern regions and the northern ones, to which connect the main trade roads (Rante et al., 2016). This ancient road, linking Kerman to Torbat-e Heydarieh to Mashhad, is still today traversed by pelerines for the pilgrimage or ziyārat to the mausoleum of Imam Reza. The discovery of the Sasanian religious places and the Islamic building, whether it be a mușalla or a caravanserai, would corroborate the fact that the valley played a role of "stopover" already under the Sasanian period and, by its key geographical and strategical location, also became a crucial crossroad during Islamic times. It is not yet clear if, since the sixth century $\mathrm{CE}$ at least, the religious role held by this valley depended on its trade, or vice versa. We are not convinced by the creation of a religious place such as that of Bazeh Hur/Qale Dokhtar untied from other factors. As previously noted, historical sources are silent about this location and archaeological evidence "only" brought to light religious features, although very significant. If this hypothesis is confirmed, there is evidence of a link already at the Sasanian period in Khorasan between trade roads and the construction of religious areas for entertaining adepts during their pilgrimage; not to mention that the valley and its landscape offered water, pasture, and a place to settle.

5

\section{Conclusion}

The valley of Robat-e Sefid/Bazeh Hur is an example of development during the last part of the Sasanian epoch, sixth century CE, of rural areas traversed by caravan roads, which implies the organization of the territory for the people crossing this path. Religious monuments were thus erected, a tradition which continued during the Islamic period.

The religious complex of Bazeh Hur shows some interesting aspects of the Sasanian traditions. Although quite well known, the custom of building atashkadeh on the top of hills or mountains, the complex linking a religious building on the relief and another religious building at the base of the relief, is quite rare. As previously noted, it is possible that both monuments belonged to the religious sphere, but they differentiated on the type of function, private or public. It seems probable that the fire temple on the top of the hill was reserved for private customs, while below was, by its location along the ancient caravan road, reserved for a larger public. Both monuments certainly shared the employ of the holy fire and some ceremonies.

During Islamic times, from at least the ninth century as attested by archaeological evidence, this tradition still exists. A square building, a caravanserai or possibly a mușalla , was erected in isolated areas. The presence of quality ceramic in Abbas Abad would testify that the building was occupied by pilgrims or by high Islamic society, which traversed this valley to reach other major cities. This archaeological evidence could exclude the possibility that the building was occupied exclusively for military reasons.

\section{About the Authors}

Rocco Rante is an archaeologist at the Louvre Museum. He obtained a habilitation in France, University Paris Sorbonne-Panthéon, and obtained the title of Professor of Universities from the National Centre of Universities. He is a specialist in the population 
and urban dynamics of the Iranian world, from the Parthian time to the early Islamic period. He directs the Archaeological Mission in the Bukhara Oasis in collaboration with Djamal Mirzaakhmedov and the Archaeological Mission in Khorasan in collaboration with Meysam Labbaf-Khaniki.

Meysam Labbaf-Khaniki is an assistant professor at the University of Tehran. His research interest includes Sasanian art and archaeology with a focus on the material culture of northeastern Iran. He has directed archaeological expeditions to Sasanian archaeological sites in this region, including Nishapur, Kalat, and Bazeh Hur.

\section{Bibliography}

Afzal al-Molk, Gh. (1903). Safarname-ye Khorāsān va Kermān. Edited by Gh. Roshani. Tehran: Tous Publication.

Azarnoush, M. (1994). The Sasanian Manor House at Hajiabad, Iran. Florence: Monografie di Mesopotamia 3.

Bellew, H.W. (1874). From the Indus to the Tigris. London: Trübner.

Bier, L. (1986). Sarvistan: A Study in Early Iranian Architecture. University Park: Pennsylvania State University Press.

Bivar, A.D.H. (1970). Trade between China and the Near East in the Sassanian and Early Muslim Period. Colloquies on Art and Archaeology in Asia, No. 1, Pottery and Metalworks in T'ang China. London: University of London, pp. 1-8.

Boyce, M. (2011). Ādur Gušnasp. In: Enyclopaedia Iranica, https://bit.ly/3rysuDv.

Chegini, N.N. (1996). Sasanian Iran: Political History, Economy and Society. In: History of Civilizations of Central Asia, Volume 3, UnEsco, pp. 40-59.

Diez, E. (1923). Islamische Baukunst in Churasan. Hagen: Volkwang-Verlag.

Fraser, J.B. (1984). Narrative of a Journey into Khorasan in the Years 1821 and 1822. Oxford: Oxford University Press.

Frye, R. (1983). The Political History of Iran under the Sasanians. In: E. Yarshater, ed., The Cambridge History of Iran, Volume 3, Part 1, Cambridge: Cambridge University Press, pp. 116-81.

Ghanimati, S. (2001). Kuh-e Khwaja: A Major Zoroastrian Temple Complex in Sistan, $\mathrm{PhD}$ Thesis, Department of Near Eastern Studies, University of California, Berkeley.

Ghirshman, R. (1962). Persian Art: The Parthian and Sassanian Dynasties, 249 BC-AD 651. New York: Golden Press.

Godard, A. (1938). Les monuments du feu. Athar-e Iran 3. Paris.

Gyselen, R. (1989). La géographie administrative de l'Empire sassanide. Leuven: Peeters.

Gyselen, R. (2003). La reconquête de l'est iranien par l'empire sassanide au VIe siècle, d'après les sources "iraniennes." Arts Asiatiques 58, pp. 162-67.

Hallier, U. (1975). Ribat-i Sefid (Khorāsān). Archaeologische Mitteilungen aus Iran 8, pp. 143-66.

Herzfeld, E. (1942). Damascus: Studies in Architecture. Ars Islamica 9, pp. 1-53.

Hozhabri, A. (2013). The Evolution of Religious Architecture in the Sasanian Period. Sasanika Online, Archaeology 18, www.sasanika.org/wp-content/uploads/e-sas-AR-18-The-Evolutionof ReligiousArchitecture.pdf.

Huff, D. (1975).Sasanian Čahar Taqs in Fars. In:F. Bagherzadeh, ed., Proceedings of the Third Annual Symposium on Archaeological Research in Iran, Tehran: National Centre for Archaeological Research, pp. 243-54.

Huff, D. (1989). BĀZA-HŪR. In: Encyclopaedia Iranica 4, Fasc. 1, 20. Edited by E. Yarshater. Costa Mesa: Mazda Publishers.

Kleiss, W. (1978). Kuppel- und Rundbauten aus sasanidischer und islamischer Zeit. Archaeologische Mitteilungen aus Iran 11, pp. 151-66. 
Labbaf-Khaniki, M. (2017). Excavations at Bazeh-Hur in North-Eastern Iran: A Preliminary Report. Iran 55, pp. 253-70.

Labbaf-Khaniki, M. (2019). Trial Trenching and Discovery of a Columned Building in Bazeh-Hur (North-East Iran). Iran 58/2, pp. 221-35.

Labbaf-Khaniki, R. (1378/1999). Sima-ye Miras-e Farhangi-ye Khorāsān. Tehran: ICHO.

Labbaf-Khaniki, R. (2006). Nishapur Excavation. Unpublished Report.

Labbaf-Khaniki, R., Shahri, M.B., and Na'mati, B. (1392/2013). Karavanserahay-e Khorasan. In: Pajuheshgah-e sazeman-e Miras-e Faranghi-e Sanay'va Gardeshgary. Tehran.

Marquart, J. (1901). Eranshahr nach der Geographie des ps. Moses Xorenac'i. Frankfurt: Weidmannsche Buchhandlung.

Monshi, M.A. (1356/1978). Safarname-ye Rokn al-Dowlah. Edited by M. Golbon. Tehran: Sahar Publication.

Moorey, P.R.S. (1979). Kish Excavations 1923-1933, Ashmolean Museum. Oxford: Clarendon Press.

Naumann, R. (1967). Takht-i Suleiman. Survey of Persian Art 16, pp. 3050-6o.

Pigulevskaja, N. (1951). Vizantija na putjax v Indiju. Iz istorii torgovli Vizantii s Vostokom v IV-VI vv. [Byzantium on the Routes to India: On the History of Byzantine Trade with the East in the Fourth to Sixth Centuries]. Moscow/Leningrad.

Pirnia, M.K. (1386/2007). Sabk Shenasi-ye Me'mari-ye Irani. Tehran: Soroush-e Danesh.

Rahbar, M. (2004). Le Monument Sassanide de Bandiān, Dargaz: un temple du feu d'après les dernières découvertes 1996-98. Studia Iranica 33, pp. 7-30.

Rante, R. (2015). "Proper Khorasan" and "Great Khorasan," within a Politico-cultural Framework. In: R. Rante, ed., The Greater Khorasan, Supplement de Der Islam, Berlin: De Gruyter, pp. 9-26.

Rante, R., Fouache, E., and Mirzaakhmedov, D. (2016). Dynamics of Human Settlements Ensuing from River Transformation and Changes in Commercial Behavior: The Birth of the "NorthEastern Silk Road." Journal of Archaeological Science: Reports 9, pp. 437-47.

Rezakhani, Kh. (2017). ReOrienting the Sasanians: East Iran in Late Antiquity. Edinburgh: Edinburgh University Press.

Schippmann, K. (1971). Die iranischen Feuerheiligtümer. Berlin: Walter De Gruyter.

Siroux, M. (1949). Caravansérails d'Iran et petites constructions routières. Mémoires publiées par les membres de l'Institut français d'archéologie du Caire. Le Caire.

Tomaschek, W. (1972). Zur historischen Topographie von Persien. Osnabrück.

Wilkinson, C.K. (1986). Nishapur: Some Early Islamic Buildings and Their Decoration. New York: Metropolitan Museum of Art.

\section{Notes}

1 Tomaschek (1972: 83-7) identified these two sites respectively as Palitas and Parhe on the Tabula Peutingeriana.

2 All altitudes given in this article are indicated as "above sea level" (asl).

3 We would like to thank Eric Fouache for his precious attention and suggestions about this subject.

4 People living in Bazeh Hur, the village west to the valley, which seems to be more ancient than Robat-e Sefid, knew the existence of gypsum mines even before the 1960 .

5 Regarding Nishapur stuccoes, see Wilkinson (1986) and Labbaf-Khaniki (2006).

6 According to the indigenous people of the region, Qaleh Pesar was located over the summit of the mountain on the eastern side of the ancient road/gorge. They believe that this castle was connected to Qale Dokhtar on either side. On the other hand, according to Herzfeld's diary, "the čahārțāq was called kaleh-i dukhtar and the fortifications to the south of the čahārțāq were known as kaleh-i pisar" (Herzfeld, 1942: 33). There is no oral or textual record in which the southeastern feature was called Qaleh Pesar.

7 For an exhaustive description of the monument, see Labbaf-Khaniki (2017).

8 Godard (1938: 54) proposed a prior third-century date, although no substantial elements were provided.

9 Labbaf-Khaniki and Rante are currently working on an exhaustive description of the site. 
10 Concerning monuments on the top of a hill or mountain, Siroux was among the first to publish on the Qaleh Dukhtar of Shahrestanek, presenting not only a residential side but also its strategic and military one (Godard, 1938: 123-32), supervising four valleys on the Elborz reaching the plain of Varamin coming from Mazandaran. Another monument which seems closer to that of Bazeh Hur has also been highlighted by Siroux (Godard, 1938: 113-20), the Qaleh Dokhtar of Qom. According to Siroux, this latter monument concentered both military and religious functions. Although far from the function of the Qaleh Dokhtar of Bazeh Hur, these monuments on the top of hills, no matter their main function, also had the role of inspecting the landscape. Robat-e Sefid/Bazeh Hur is located at the entry of the main area of the Abarshahr, where are situated Nishapur, Tus, and the main caravan road.

11 Among the large literature concerning the architecture of Sasanian fire temples constituted of a chahartaq and its ambulatory, we can mention the fire temples of Bishapur (Ghirshman, 1962; Schippmann, 1971), although we have not the same cruciform plan in Bazeh Hur, Kuh-e Khwaja (Ghanimati, 2001), Takht-e Soleiman (Boyce, 2011; Naumann, 1967; Schippmann, 1971), or Hajiabad (Azarnoush, 1994).

12 The presence of the ancient road and that of the Safavid caravanserai help us to see this monument as a caravanserai. Nonetheless, its location so far from the ancient road, the later caravanserai leading just along the road, and the religious Sasanian heritage of Bazeh Hur could probably push us to identify it as a rural religious building. Mușallās in Khorasan are known, although no deeper studies have been carried out. Godard, to my knowledge, has been among the first to highlight these monuments (Godard, 1938: 125-37). He published two major examples, the mușalla of Turuk and that of Mashhad, which probably are more elaborated than our example.

13 Siroux has been one of the first to mention this caravanserai (Siroux, 1949: 21). Before him, Mohammad Ali Monshi in 1882 and Gholamhosein Khan Afzal al-Molk in 1893 have described Robat-e Sefid. According to Monshi the roofed area of the carvanserai has been built by Mahmoud $b$. Hosein Torshizi during the reign of Shah Tahmasb the Safavid in 967/156o (Monshi, 1356/1978: 126). As Afzal al-Molk has reported, the courted portion of the caravanserai was constructed in the Qajar period by Amin al-Tojjar abutting the older roofed part (Afzal al-Molk, 1903: 129).

14 For architectural details, see Labbaf-Khaniki et al. (1392/2013: 375-80).

15 Regarding Khorasan and eastern Iranian territories, see Gyselen (2003: 162-7).

16 Although we do not miss publications about trade in Sasanian times, it is interesting to glance at the still valid work of Pigulevskaja (1951), in which the scholar brought to light the trade from Byzantium until India. See also Bivar (1970); Chegini (1996: 48). 